\title{
Article \\ Changes in Growth, Photosynthesis Performance, Pigments, and Toxin Contents of Bloom-Forming Cyanobacteria after Exposure to Macroalgal Allelochemicals
}

\author{
Gracjana Budzałek $^{1}{ }^{(}$, Sylwia Śliwińska-Wilczewska ${ }^{1}{ }^{1} *$ (D) Marek Klin ${ }^{1}$, Kinga Wiśniewska $^{2}\left(\mathbb{D}\right.$, Adam Latała $^{1}$ \\ and Józef Maria Wiktor ${ }^{3}$ \\ 1 Division of Marine Ecosystems Functioning, Institute of Oceanography, University of Gdańsk, \\ Piłsudskiego 46, P-81-378 Gdynia, Poland; gbudzalek@gmail.com (G.B.); marek.klin@ug.edu.pl (M.K.); \\ adam.latala@ug.edu.pl (A.L.) \\ 2 Division of Marine Chemistry and Environmental Protection, Institute of Oceanography, University of \\ Gdańsk, Piłsudskiego 46, P-81-378 Gdynia, Poland; kinga.wisniewska@phdstud.ug.edu.pl \\ 3 Department of Marine Ecology, Institute of Oceanology of the Polish Academy of Sciences, Powstańców \\ Warszawy 55, P-81-712 Sopot, Poland; wiktor@iopan.pl \\ * Correspondence: ocessl@ug.edu.pl; Tel.: +48-58-523-68-94
}

check for updates

Citation: Budzałek, G.;

Śliwińska-Wilczewska, S.; Klin, M.; Wiśniewska, K.; Latała, A.; Wiktor,

J.M. Changes in Growth,

Photosynthesis Performance,

Pigments, and Toxin Contents of

Bloom-Forming Cyanobacteria after

Exposure to Macroalgal

Allelochemicals. Toxins 2021, 13, 589.

https://doi.org/10.3390/toxins

13080589

Received: 30 June 2021

Accepted: 20 August 2021

Published: 23 August 2021

Publisher's Note: MDPI stays neutral with regard to jurisdictional claims in published maps and institutional affiliations.

Copyright: (c) 2021 by the authors. Licensee MDPI, Basel, Switzerland. This article is an open access article distributed under the terms and conditions of the Creative Commons Attribution (CC BY) license (https:/ / creativecommons.org/licenses/by/ $4.0 /)$.

\begin{abstract}
Macroalgae can directly restrict the growth of various phytoplankton species by releasing allelopathic compounds; therefore, considerable attention should be paid to the allelopathic potential of these organisms against harmful and bloom-forming cyanobacteria. The main aim of this study was to demonstrate for the first time the allelopathic activity of Ulva intestinalis on the growth, the fluorescence parameters: the maximum PSII quantum efficiency $\left(F_{\mathrm{v}} / F_{\mathrm{m}}\right)$ and the effective quantum yield of PSII photochemistry (ФPSII), the chlorophyll $a(\mathrm{Chl} a)$ and carotenoid (Car) content, and the microcystin-LR (MC-LR) and phenol content of three bloom-forming cyanobacteria, Aphanizomenon sp., Nodularia spumigena, and Nostoc sp. We found both negative and positive allelopathic effects of $U$. intestinalis on tested cyanobacteria. The study clearly showed that the addition of the filtrate of $U$. intestinalis significantly inhibited growth, decreased pigment content and $F_{\mathrm{v}} / F_{\mathrm{m}}$ and $\Phi P S I I$ values of N. spumigena and Nostoc sp., and stimulated Aphanizomenon sp. The addition of different concentrations of aqueous extract also stimulated the cyanobacterial growth. It was also shown that the addition of extract obtained from $U$. intestinalis caused a significant decrease in the MC-LR content in Nostoc sp. cells. Moreover, it the phenol content in N. spumigena cells was increased. On the other hand, the cell-specific phenol content for Aphanizomenon sp. decreased due to the addition of the filtrate. In this work, we demonstrated that the allelopathic effect of $U$. intestinalis depends on the target species' identity as well as the type of allelopathic method used. The study of the allelopathic Baltic macroalgae may help to identify their possible role as a significant biological factor influencing harmful cyanobacterial blooms in brackish ecosystems.
\end{abstract}

Keywords: allelopathy; green algae; macroalgae; secondary metabolites; toxic cyanobacteria

Key Contribution: In this study, we demonstrated that $U$. intestinalis effectively inhibits the growth of Baltic cyanobacteria N. spumigena and Nostoc sp. Thus, the results obtained in this study provide new insights into the ecological role of macroalgae $U$. intestinalis in reducing the occurrence of certain massive bloom-forming cyanobacteria species in the Baltic Sea region. On the other hand, we also found positive allelopathic effects of $U$. intestinalis on another toxic cyanobacterium Aphanizomenon sp. These results may indicate that in areas where there are underwater meadows and/or large biomass of $U$. intestinalis, Aphanizomenon sp. may appear in large quantities.

\section{Introduction}

Macroalgal allelopathy is considered to be a special strategy to deter or eliminate competitors and predators coexisting in a shared ecosystem [1]. The secondary metabolites 
produced and secreted into the environment by donor organisms have been called allelopathic compounds [2]. Macroalgal allelopathy depends on the production and secretion of active allelopathic compounds and their efficient dispersal to target organisms that were affected by these compounds [3]. These compounds can not only affect other plants, but also cyanobacteria, protists, zooplankton, bivalves, crustaceans, and fish by limiting their reproduction and causing high mortality [4,5]. Allelopathic compounds can also affect the growth and photosynthesis of coexisting cyanobacteria and microalgae (e.g., [6-9]). However, many of the mechanisms of action of allelopathic compounds are not fully understood [10].

Allelopathy in aquatic ecosystems occurs in coastal areas where macroalgae and macrophytes are often present [11-17]. Macroalgae in the aquatic environment belong to green (Chlorophyta and Charophyta), red (Rhodophyta), and brown (Ochrophyta) algae. Macroalgae have been found to produce active metabolites that inhibit other organisms that compete with them for nutrients, light or space $[18,19]$. Thus, the competition for resources may be crucial in the occurrence of allelopathic interactions. Furthermore, the bottom in the littoral zone is limited compared to the pelagic offshore; thus, allelopathic interactions in coastal ecosystems may be stronger [20]. Consequently, allelopathic interactions may contribute to changes in phytoplankton and phytobenthic structures in aquatic ecosystems, especially in shallow waters [20].

Some studies have shown that compounds secreted by green macroalgae Cladophora glomerata inhibited the growth of the epiphytic diatom Nitzschia sp. [21]. In contrast, Anthoni et al. [22] suggested that the low abundance of epiphytes on Chara globularis thallus indicated that these macroalgae were probably also capable of producing harmful, unidentified allelopathic compounds. Seven years later, Anthoni et al. [23] isolated a compound called charamin, extracted from this species, which exhibited strong antibiotic activity. Two sulfur compounds (dithiolate and trithiane) isolated from C. globularis were also shown to inhibit the growth of the diatom Nitzschia palea and to reduce the abundance of natural phytoplankton communities [24,25]. In contrast, Mulderij et al. [26] studied the allelopathic activity of two species of C. globularis and Chara contraria on three species of green microalgae: Selenastrum capricornutum, Chlorella minutissima, and Scenedesmus obliquus. The growth of $S$. capricornutum and C. minutissima was shown to be negatively affected by both green macroalgae, while the growth of S. obliquus was not inhibited. On the other hand, other laboratory studies showed that $C$. globularis significantly inhibited the growth of Scenedesmus sp. [27]. Studies have confirmed also that marine macroalgae such as Corallina pilulifera (Rhodophyta), Ulva pertusa (Chlorophyta), Ishige foliacea (Ochrophyta), and Endarachne binghamiae (Ochrophyta) are capable of secreting allelopathic compounds [19], which inhibit the growth of the toxic and bloom-forming Miozoa Cochlodinium polykrikoides. Interestingly, the C. pilulifera secreted allelopathic compounds that did not inhibit the growth of many other non-toxic microalgae. The inhibitory effect of Ulva lactuca on microalgae of the genus Aureococcus [28], and the inhibitory effect of the extract of U. pertusa, C. pilulifera, and Sargassum thunbergii on dinoflagellates [29] has been demonstrated. In addition, the effects of $U$. petrusa on Heterosigma akashiwo and Alexandrium tamarense were investigated [30]. Based on the examples mentioned above, it can be assumed that some macroalgae exhibit diverse allelopathic compounds that depend on both donor and target organism.

There are also numerous reports on the allelopathic effect of macrophytes on various cyanobacteria species $[11,12,14,15,20,31-40]$. Among these studies, allelopathic activity of thallophytes belonging to the genera Ceratophyllum, Myriophyllum, Potamogeton, and Stratiotes is the most commonly reported. Mulderij et al. [33] demonstrated the inhibitory effect of the filtrate from Stratiotes aloides on two cyanobacteria, the toxic and non-toxic Microcystis aeruginosa. Interestingly, a greater negative effect of the filtrate was noted for the toxic strain of tested cyanobacteria. Two years later, Mulderij et al. [34] studied how the extract and filtrate of S. aloides affected the phytoplankton community. The authors showed that $S$. aloides had both stimulatory and inhibitory effects on phytoplankton assemblages. In addition, the authors noted that inhibition of abundance and biomass was recorded mainly 
in the case of cyanobacteria. Körner and Nicklisch [11] studied the effect of allelopathic compounds from living tissue of vascular plants Myriophyllum spicatum, Ceratophyllum demersum, and Potamogeton pectinatus. They showed that among cyanobacteria, Microcystis aeruginosa was more sensitive than the cyanobacterium Aphanizomenon flos-aquae. Moreover, growth inhibition of tested cyanobacteria was positively dependent on $M$. spicatum biomass. Experiments on the vascular plant $M$. spicatum were also conducted by Leu et al. [12]. They studied the effect of M. spicatum extract on the cyanobacteria Anabaena sp., Synechocystis sp., and Synechococcus sp. The allelopathic compounds secreted by this plant inhibited oxygen production in the cyanobacteria Anabaena sp. Erhard and Gross [40] studied the effect of extract from two vascular plants: Elodea canadensis and Elodea nuttallii, on microalgae and cyanobacteria forming natural phytoplankton and phytobenthic communities. Based on the obtained results, Erhard and Gross [40] concluded that allelopathic compounds produced by aquatic plants may reduce the biomass of some organisms, especially cyanobacteria, due to their relatively high sensitivity. On the other hand, Ghobrial et al. [37] showed that the extract of two freshwater vascular plants Potamogeton pectinatus and Ceratophyllum demersum stimulated the growth of the cyanobacteria Microcystis aeruginosa and Oscillatoria tenuis. Moreover, Aliotta et al. [39] studied the effect of Typha latifolia extract on a wide range of cyanobacteria species (Nostoc commune, Synechococcus leopoliensis, Anabaena flos-aquae, Phormidium autumnale, Porphyrosiphon notarisii, Aulosira terrestre, and Scytonema hofmanni). The authors showed that T. latifolia extract both inhibited and stimulated the growth of tested cyanobacteria. Moreover, the effect was dependent on the target organism.

Compared to the extensive research on allelopathic interactions among aquatic plants mentioned above, knowledge on macroalgal allelopathy on cyanobacteria in aquatic habitats is still fragmentary. Therefore, in this study, two different methods involving the addition of extract and cell-free filtrate obtained from $U$. intestinalis were used to determine their effects on the growth, photosynthetic activity, pigment, and toxin content of three of the Baltic bloom-forming cyanobacteria, Aphanizomenon sp., Nodularia spumigena, and Nostoc sp. The study may help to identify the possible role of common macroalgae $U$. intestinalis as a significant biological factor influencing harmful cyanobacterial blooms in brackish ecosystems.

\section{Results}

\subsection{Effect of Ulva intestinalis Extracts and Cell-Free Filtrate on Cyanobacterial Growth}

In order to investigate the effect of Ulva intestinalis on the growth of three filamentous cyanobacteria Aphanizomenon sp. BA69, N. spumigena BA15, and Nostoc sp. BA81, the experiments with different concentration of extract and cell-free filtrate additions after 7 and 14 days of the expositions were conducted (Figure 1).

Generally, the addition of aqueous extract of $U$. intestinalis significantly increased the growth of tested cyanobacteria. The growth of Aphanizomenon sp. after addition of 25 and $50 \mu \mathrm{L} \mathrm{mL} \mathrm{m}^{-1}$ of extracts, increased, relative to the control, $187 \%$ and $214 \%$ after 7 days of the expositions, respectively, and $298 \%$ and $299 \%$, respectively, after two weeks of the aqueous extracts' expositions (Figure 1A). The growth of N. spumigena was affected by extract of $U$. intestinalis already at day 7 , being, relative to the control, $288 \%, 312 \%$, and $998 \%$ with 5,25 , and $50 \mu \mathrm{L} \mathrm{mL}^{-1}$ additions of the aqueous extracts, respectively (Figure 1B). On the 7th day, the growth of Nostoc sp. was, relative to the control, $149 \%, 162 \%$, and $160 \%$ after the 5, 25, and $50 \mu \mathrm{L} \mathrm{mL}^{-1}$ aqueous extracts' additions, respectively. On the 14th day, the growth of this cyanobacterium was stimulated by $227 \%$ and $180 \%$ with 5 and $25 \mu \mathrm{L} \mathrm{mL}^{-1}$ additions of the extract, respectively (Figure 1C).

On the other hand, it was shown that the cell-free filtrate addition resulted in a decrease in the number of N. spumigena and Nostoc sp. cells. In the case of N. spumigena, the highest decrease in growth was observed after addition of the $25 \mu \mathrm{L} \mathrm{mL}^{-1}$ of filtrate addition, decreasing by $15 \%$ after 7 days of the experiment, relative to the control; however, this result was not statistically significant. However, significant reduction in growth occurred after 14 days. The growth was, relative to the control, $48 \%, 37 \%$, and $43 \%$, after addition of 5,25 , 
and $50 \mu \mathrm{L} \mathrm{mL}^{-1}$ of filtrate, respectively (Figure 1B). In experiments with Nostoc sp. and $U$. intestinalis cell-free filtrate addition, the negative effect on growth was detected on the 7th day of exposure at $50 \mu \mathrm{L} \mathrm{mL}^{-1}$ and constituted $75 \%$ of control (Figure 1C). Surprisingly, as was the case with the extract, the stimulation of the growth of Aphanizomenon sp. was noted after addition of the cell-free filtrate obtained from $U$. intestinalis. The growth of Aphanizomenon sp. was affected on the 7th day by $U$. intestinalis at $25 \mu \mathrm{L} \mathrm{mL}^{-1}$ of filtrate, being, relative to the control, $143 \%$ (Figure 1A).

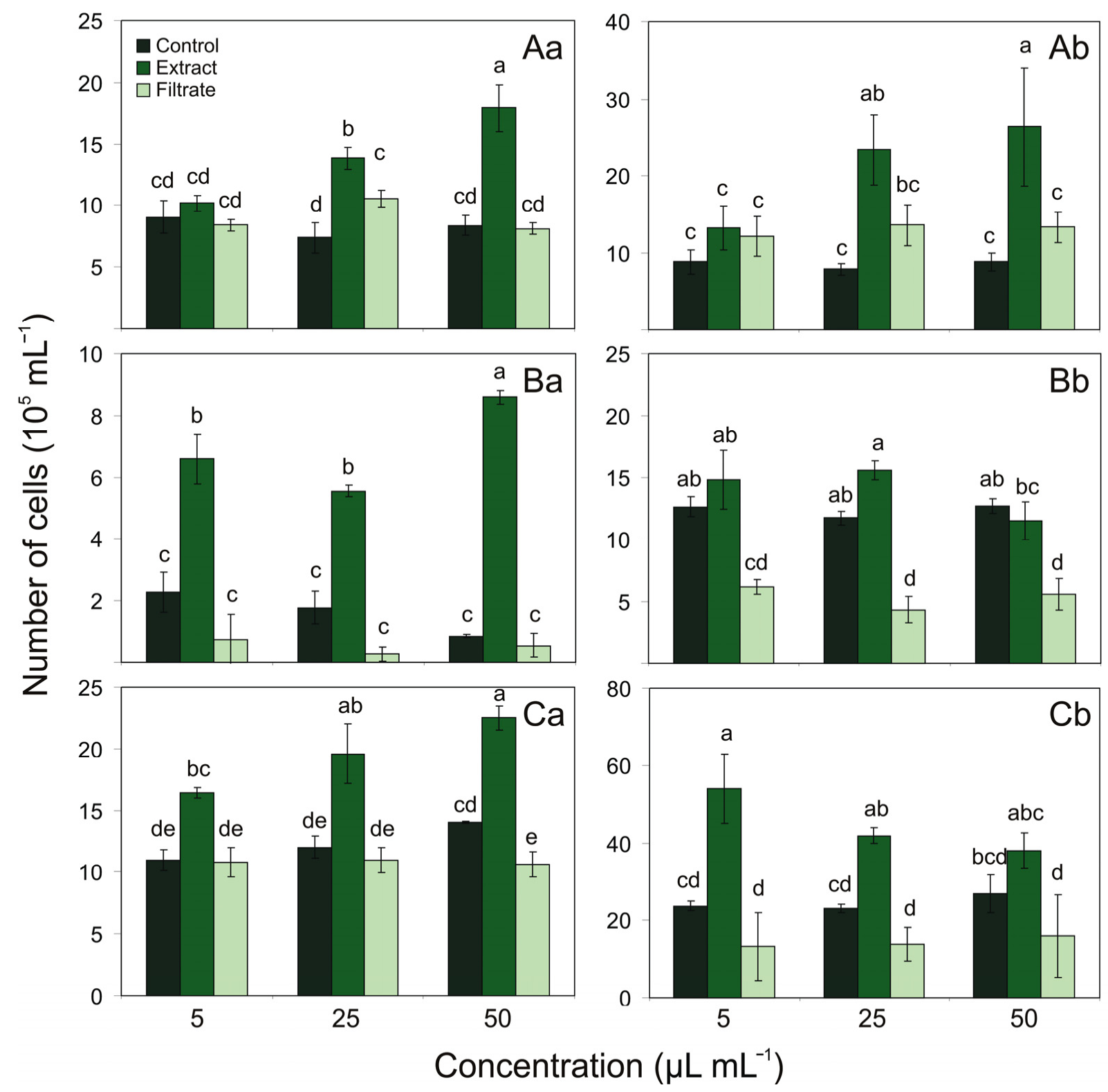

Figure 1. Number of cells $\left(\mathrm{N}=10^{5}\right.$ cell $\left.\mathrm{mL}^{-1}\right)$ for Aphanizomenon sp. BA69 (A), N. spumigena BA15 (B), and Nostoc sp. BA81 (C) for controls and treatments with different concentrations of extract and cell-free filtrate additions obtained from macroalgae $U$. intestinalis after $7(\mathbf{a})$ and $14(\mathbf{b})$ days of the expositions $(n=3)$. Different letters indicate significant differences between the means of the treatments ( $p<0.05$, one-way ANOVA). Error bars display the standard deviation.

\subsection{Effect of Ulva intestinalis Extracts and Cell-Free Filtrate on the Pigments Content}

The effects of different concentrations of aqueous extract and cell-free filtrate additions obtained from green macroalgae $U$. intestinalis on the $\mathrm{Chl} a$ and Car content of tested cyanobacteria after 7 days of the expositions are shown in Figure 2. The Car content of 
Aphanizomenon sp. was negatively affected after addition of $5 \mu \mathrm{L} \mathrm{mL}{ }^{-1}$ of extracts, being, relative to the control, 23\% (Figure 2A). Surprisingly, addition of extract and filtrate of $U$. intestinalis did not affect Chl $a$ and Car content of N. spumigena (Figure 2B). In the case of cell-free filtrate addition obtained from $U$. intestinalis, the Chl $a$ content in Nostoc sp. constituted $36 \%$ at $25 \mu \mathrm{L} \mathrm{mL}^{-1}$ and $32 \%$ at $50 \mu \mathrm{L} \mathrm{mL}^{-1}$, relative to the control. Furthermore, the significant negative effect on Car content was found for this cyanobacterium in the filtrate addition experiment (at $25 \mu \mathrm{L} \mathrm{mL}^{-1}$ ), for which it constituted $36 \%$ of the control. The Car content of Nostoc sp. was also affected after addition of 5 and $50 \mu \mathrm{L} \mathrm{mL}^{-1}$ of extracts, being, relative to the control, $222 \%$ and $186 \%$, respectively (Figure $2 \mathrm{C}$ ).

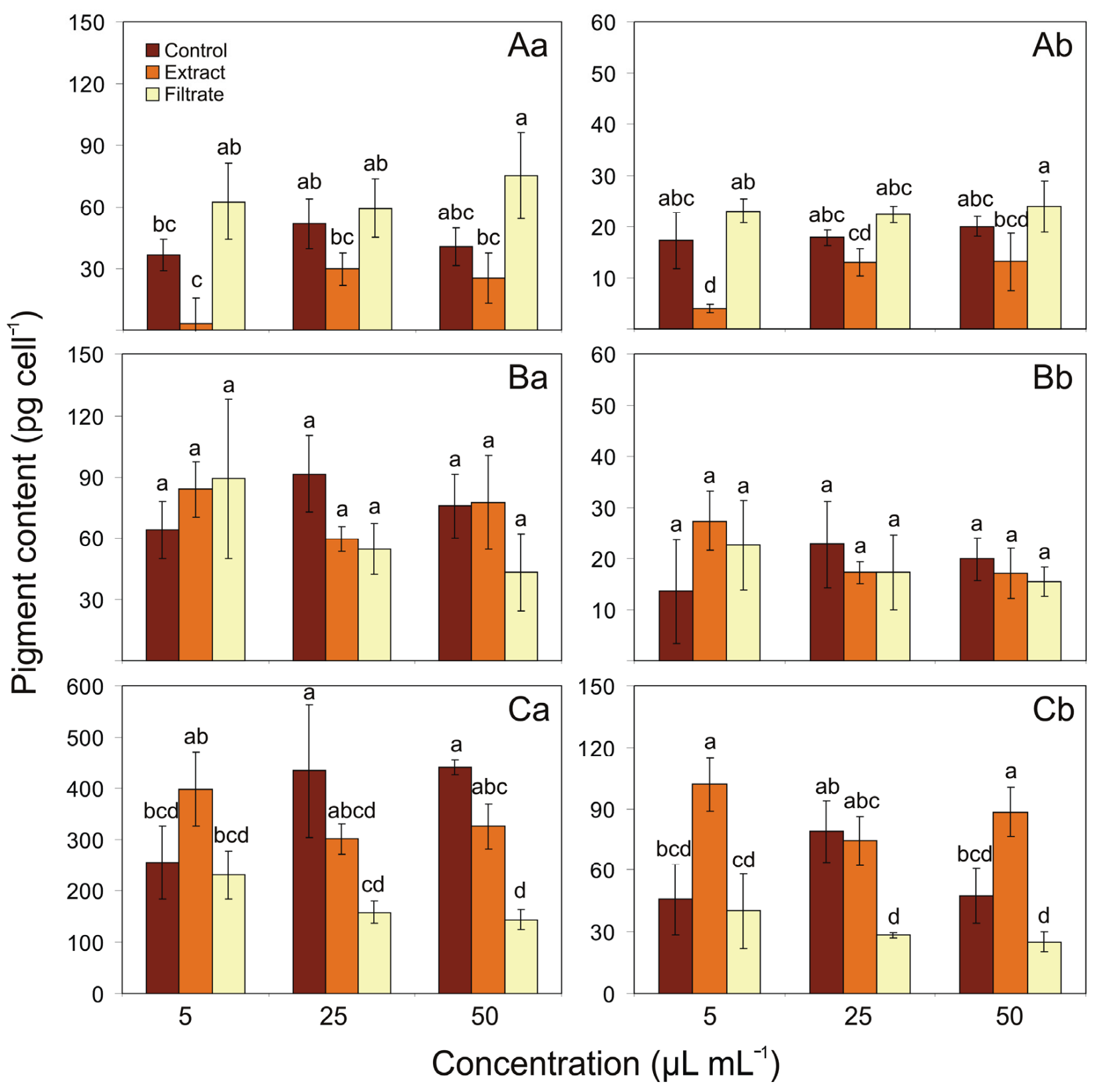

Figure 2. Chl $a\left(\mathrm{pg}\right.$ cell $\left.{ }^{-1} ; \mathbf{a}\right)$ and Car (pg cell $\left.{ }^{-1} ; \mathbf{b}\right)$ content for Aphanizomenon sp. BA69 (A), N. spumigena BA15 (B), and Nostoc sp. BA81 (C) for controls and treatments with different concentrations of extract and cell-free filtrate additions obtained from macroalgae $U$. intestinalis after 7 days of the expositions $(n=3)$. Different letters indicate significant differences between the means of the treatments ( $p<0.05$, one-way ANOVA). Error bars display the standard deviation. 


\subsection{Effect of Ulva intestinalis Extracts and Cell-Free Filtrate on Fluorescence Parameters}

The effects of different concentrations of aqueous extract and cell-free filtrate additions from $U$. intestinalis after 7 days of the expositions on the maximum quantum yield of PSII photochemistry $\left(F_{\mathrm{v}} / F_{\mathrm{m}}\right)$ as well as the effective quantum yield of PSII photochemistry (ФPSII) in cyanobacterial cells are shown in Figure 3.

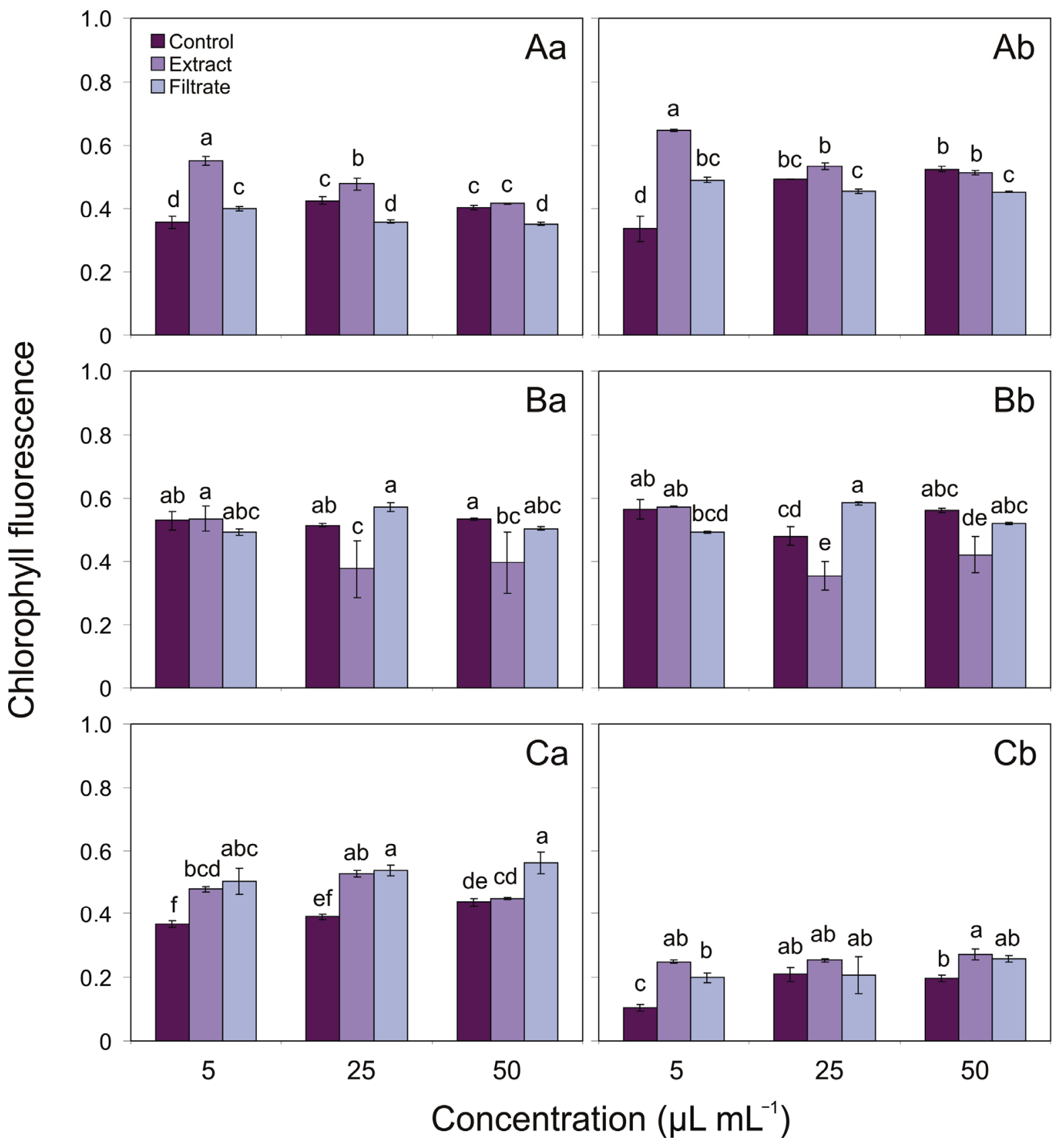

Figure 3. $F_{\mathrm{v}} / F_{\mathrm{m}}(\mathbf{a})$ and $\Phi P S I I$ (b) parameters for Aphanizomenon sp. BA69 (A), N. spumigena BA15 (B), and Nostoc sp. BA81 (C) for controls and treatments with different concentrations of extract and cell-free filtrate additions obtained from macroalgae $U$. intestinalis after 7 days of the expositions $(n=3)$. Different letters indicate significant differences between the means of the treatments $(p<0.05$, one-way ANOVA). Error bars display the standard deviation.

In the extract addition experiments, in Aphanizomenon sp., the effect on $F_{\mathrm{v}} / F_{\mathrm{m}}$ and SPSII parameters increased by $154 \%$ and $191 \%$, respectively, at the concentration of $5 \mu \mathrm{L} \mathrm{mL}^{-1}$. Moreover, the $F_{\mathrm{v}} / F_{\mathrm{m}}$ increased by $112 \%$, relative to the level at the control treatment, at the concentration of $25 \mu \mathrm{L} \mathrm{mL}^{-1}$. On the other hand, for cell-free filtrate 
addition obtained from $U$. intestinalis, the $F_{\mathrm{v}} / F_{\mathrm{m}}$ in the mentioned cyanobacterium constituted, respectively, $112 \%$ at $5 \mu \mathrm{L} \mathrm{mL}^{-1}, 84 \%$ at $25 \mu \mathrm{LL}^{-1}$, and $86 \%$ at $50 \mu \mathrm{L} \mathrm{mL}^{-1}$, relative to the control. The $\Phi P S I I$ parameters of Aphanizomenon sp., after the addition of 5 and $50 \mu \mathrm{L} \mathrm{mL}^{-1}$ of cell-free filtrate, constituted $145 \%$ and $86 \%$, respectively (Figure $3 \mathrm{~A}$ ). Regarding the $F_{\mathrm{v}} / F_{\mathrm{m}}$ parameter, for $N$. spumigena in the extract addition assay, it was $73 \%$ at a concentration of $25 \mu \mathrm{L} \mathrm{mL}^{-1}$ and $74 \%$ at a concentration of $50 \mu \mathrm{L} \mathrm{mL}^{-1}$, relative to the control. Furthermore, in N. spumigena, the significant decrease in the ФPSII parameter was observed after 25 and $50 \mu \mathrm{L} \mathrm{mL}^{-1}$ of extract addition, being $73 \%$ and $75 \%$, respectively. For this same species, it was found that after addition of $25 \mu \mathrm{L} \mathrm{mL}^{-1}$ of macroalgal filtrate concentrations, the values of $\Phi P S I I$ constituted $121 \%$ (Figure 3B). Interestingly, the addition of extract and filtrate obtained from $U$. intestinalis significantly increased the fluorescence parameters of Nostoc sp. It was found that the additions of 5 and $25 \mu \mathrm{L} \mathrm{mL}^{-1}$ of extract concentrations resulted in an increased $F_{\mathrm{v}} / F_{\mathrm{m}}$ for this cyanobacterium after the seventh day of exposure, i.e., increases of $130 \%$ and $135 \%$, respectively, compared with control. Moreover, the addition of macroalgal filtrate at the concentration of 5, 25, and $50 \mu \mathrm{L} \mathrm{mL}^{-1}$ resulted in an increased $F_{\mathrm{v}} / F_{\mathrm{m}}$ value for Nostoc sp. after 1 week of exposure (by $137 \%$, $137 \%$, and by $127 \%$, respectively). The $\Phi$ PSII of Nostoc sp. was positively affected after addition of 5 and $50 \mu \mathrm{L} \mathrm{mL}^{-1}$ of extracts, being, relative to the control, $239 \%$ and $137 \%$, respectively. In the cell-free filtrate addition experiments, the values of SPSII for the mentioned cyanobacterium were significantly different from the control at the concentration of $5 \mu \mathrm{L} \mathrm{mL}{ }^{-1}$, when it constituted 202\% (Figure 3C).

\subsection{Effect of Ulva intestinalis Extracts and Cell-Free Filtrate on Microcystin and Phenol Content}

The effects of $50 \mu \mathrm{L} \mathrm{mL}{ }^{-1}$ of extract and cell-free filtrate concentrations obtained from $U$. intestinalis after 7 days of the expositions on the MC-LR and phenol content in target cyanobacteria cells are shown in Table 1. Furthermore, toxin and phenol content in cyanobacterial culture were reported in the Supplementary Material (Figure S1, Table S1).

Table 1. MC-LR (fg cell ${ }^{-1}$ ) and phenol content (ng cell ${ }^{-1}$ ) for Aphanizomenon sp. BA69 (A), $N$. spumigena BA15 (B), and Nostoc sp. BA81 (C) for controls and treatments after the aqueous extract and cell-free filtrate additions obtained from macroalgae $U$. intestinalis after 7 days of the expositions $(n=3)$. Values show arithmetic means and are followed by standard deviations in brackets. Different letters indicate significant differences between the means of the treatments $(p<0.05$, oneway ANOVA).

\begin{tabular}{|c|c|c|c|}
\hline $\begin{array}{c}\text { Target } \\
\text { Cyanobacteria }\end{array}$ & Control & Extract & Cell-Free Filtrate \\
\hline & \multicolumn{3}{|c|}{ MC-LR (fg cell ${ }^{-1}$ ) } \\
\hline Aphanizomenon sp. & ND & ND & ND \\
\hline N. spumigena & ND & ND & ND \\
\hline \multirow[t]{2}{*}{ Nostoc sp. } & $92.506(1.238)^{\mathrm{a}}$ & $16.334(4.288)^{b}$ & $85.125(4.540)^{\mathrm{a}}$ \\
\hline & \multicolumn{3}{|c|}{ Phenols (ng cell ${ }^{-1}$ ) } \\
\hline Aphanizomenon sp. & $0.329(0.010)^{b}$ & $1.322(0.016)^{\mathrm{a}}$ & $0.125(0.007)^{c}$ \\
\hline N. spumigena & $1.180(0.053)^{b}$ & $1.958(0.027)^{\mathrm{a}}$ & $1.887(0.019)^{\mathrm{a}}$ \\
\hline Nostoc sp. & $0.213(0.004)^{b}$ & $1.237(0.028)^{\mathrm{a}}$ & $0.227(0.002)^{b}$ \\
\hline
\end{tabular}

It was shown that the addition of aqueous extract obtained from $U$. intestinalis caused a significant decrease in the MC-LR content in Nostoc sp. cells and was about $18 \%$ compared to the control. On the other hand, the addition of the filtrate caused a slight decrease in the content of this toxin, but it was not statistically significant. Moreover, it was noted that two other cyanobacteria, Aphanizomenon sp. BA69 and N. spumigena BA15, were unable to produce MC-LR (Table 1).

It was also demonstrated that all tested cyanobacteria were capable of producing phenols (Table 1). Moreover, it was shown that the addition of the extract and filtrate 
obtained from $U$. intestinalis after 7 days of the expositions had a significant effect on the cell-specific phenol content of the examined cyanobacteria. It was found that the addition of the extract increased the phenol content in Aphanizomenon sp., N. spumigena, and Nostoc sp. cells, which was about 4.0-fold, 1.6-fold, and 5.8-fold higher, respectively, than the control treatments. The addition of the cell-free filtrate from $U$. intestinalis also increased the cell-specific phenol content of N. spumigena, which was about $160 \%$. Surprisingly, the addition of the cell-free filtrate caused a significant decrease (38\%) in the phenol content in Aphanizomenon sp. cells.

\section{Discussion}

\subsection{Allelopathic Activity of the Extract Obtained from $U$. intestinalis}

The present study investigated the allelopathic effects of aqueous extract and cell-free filtrate from the Baltic green macroalgae $U$. intestinalis on the growth and the physiology of three bloom-forming cyanobacteria: Aphanizomenon sp., N. spumigena, and Nostoc sp. In this study, the number of cyanobacteria was measured after 7 and 14 days in order to see how these organisms respond to allelopathic compounds produced and released by the macroalga after a longer exposure time. The results showed that extracts obtained from freshly harvested material had a stimulating effect on the tested cyanobacteria strains after the 7 days of the exposition. However, after the two weeks of the experiment, the stimulation was no longer as high or had no significant effect on the cyanobacterial growth. Extending the experiment time may have a negative effect on cell physiology due to the aging of the tested organism. Therefore, the allelopathic effect of the analyzed green macroalga on the photosynthesis performance as well as the pigments and toxin content were analyzed only after one week of exposure. In the case of the experiment on $N$. spumigena, there was even a 15-fold increase in the number of cells in the sample after one week. In the case of the Nostoc sp. growth, a significant stimulating effect of the extract additions after 7 and 14 days of the experiment was also demonstrated. Moreover, it was found that the green macroalgae extract at the lowest concentration $\left(5 \mu \mathrm{L} \mathrm{mL} L^{-1}\right)$ had no significant effect on the growth of Aphanizomenon sp. However, at higher concentrations (25 and $50 \mu \mathrm{L} \mathrm{mL}^{-1}$ ), stimulation was observed up to $187 \%$ and $214 \%$, respectively, relative to the control. In this study, we also showed that allelopathic compounds produced by Baltic macroalgae $U$. intestinalis can affect the pigment content and photosynthetic activity of target cyanobacteria. Generally, it was shown that the extract of $U$. intestinalis had no effect on the Chl a content of tested cyanobacteria. It was also shown that the Car content of Aphanizomenon sp. and Nostoc sp. was significantly changed under the influence of the extract obtained from green macroalga $U$. intestinalis. On the other hand, the addition of the extract had no effect on the Car content of N. spumigena. The Car content of Aphanizomenon sp. was negatively affected after addition of the lowest extract concentration. Surprisingly, the Car content of Nostoc sp. was also positively affected after addition of 5 and $50 \mu \mathrm{L} \mathrm{mL}{ }^{-1}$ of extracts obtained from $U$. intestinalis. Moreover, in our work we showed that fluorescence parameters of Nostoc sp. were stimulated by adding the extract obtained from donor macroalgae. For N. spumigena, the significant decrease in $F_{\mathrm{v}} / F_{\mathrm{m}}$ and $\Phi$ PSII parameters were observed after 25 and $50 \mu \mathrm{L} \mathrm{mL}^{-1}$ of extract addition. Furthermore, it was shown that higher concentrations of extract inhibited the $F_{\mathrm{v}} / F_{\mathrm{m}}$ and ФPSII of Aphanizomenon sp., while low concentrations stimulated these parameters.

Wang et al. [29] noted that high concentrations of aqueous extracts of $U$. pertusa strongly inhibited microalgae growth and caused cell degradation of $H$. akashiwo and A. tamarense. At lower extract concentrations, $U$. pertusa did not cause mortality of the test organisms and even stimulated their growth. This was probably due to the fact that at higher concentrations, all the microalgae cells were degraded by the allelopathic substances in a short time interval, whereas at lower concentrations, some microalgae cells were still alive after the degradation of some of the allelopathic compounds, allowing the remaining target cells to grow by providing them with nutrients from the dead microalgae cells. Similar observations were also made by Jin and Dong [30] when studying the effect 
of $U$. pertusa on the growth of H. akashiwo. Jin and Dong [30] showed that U. pertusa extract at relatively higher concentrations was lethal to $H$. akashiwo, while the extract at lower concentrations either had no effect on algal growth or significantly stimulated it. In this study, the stimulation of the growth of Baltic cyanobacteria Aphanizomenon sp., N. spumigena, and Nostoc sp. was also noted due to the addition of $U$. intestinalis extract. Thus, it is possible that the stimulation of cyanobacteria in the present study was due to an increase in nutrients in the medium that were contained in the $U$. intestinalis thallus and were extracted upon addition of the aqueous extract. In this study, cyanobacterial species were cultivated in the $\mathrm{f} / 2$ medium. However, some authors indicated that the $\mathrm{f} / 2$ medium is not suitable for cyanobacterial culture [41]. On the other hand, there are studies that confirm that cyanobacteria achieved the highest biomass on the f/2 medium [42]. Regardless of the medium used, it is possible that nutrient enrichment from the macroalgal extract may provide essential growth-related nutrients to cyanobacterial cells. Thus, the allelopathic effects of macroalgae on cyanobacteria maintained in various culture media should be investigated in future research.

In turn, Jin et al. [43] conducted laboratory experiments under controlled environmental conditions to investigate the allelopathic effects of $U$. pertusa and Ulva linza on Prorocentrum micans cultures. Aqueous and methanolic extracts from both Ulva species showed strong growth inhibitory effects on P. micans, while extracts from less polar organic solvents had no visible effect. This suggests that the extracted allelopathic compounds had relatively high polarity. It is noteworthy that methanolic extracts from both Ulva species showed the highest allelopathic activity. Based on the results, the authors concluded that the methanolic extracts were about 50 times more effective than the aqueous extracts. In the present study, we used aqueous extracts from $U$. intestinalis, so it can be assumed that the use of other extracts from this Baltic green macroalga could significantly enhance the observed effect.

\subsection{Allelopathic Activity of the Filtrate Obtained from U. intestinalis}

In this work, a stimulatory allelopathic effect of the filtrate obtained from $U$. intestinalis on the cyanobacterium Aphanizomenon sp. and an inhibitory effect for N. spumigena and Nostoc sp. were demonstrated. The number of Aphanizomenon sp. cells increased under the $U$. intestinalis filtrate additions in the first week of the experiment. It was shown that after the two weeks of the experiment, for each of the three concentrations, a decrease in the number of cells of N. spumigena was observed. In the case of Nostoc sp. growth, the inhibitory effect of the green macroalgae filtrate was demonstrated only after 7 days of the experiment. However, it should be noted here that not every concentration of the filtrate contributed to a change in the number of cyanobacteria cells in the experiment. Moreover, in this study, reduction in cell-specific Chl $a$ content was noted only for Nostoc sp. upon addition of the macroalgal cell-free filtrate. The addition of the filtrate had no effect on the Chl $a$ and Car content of Aphanizomenon sp. and N. spumigena. On the other hand, the significant negative effect on $\mathrm{Chl} a$ and Car content was found for Nostoc sp. in the filtrate addition experiment. In addition, the effects of filtrate from the green alga $U$. intestinalis on the values of fluorescence parameter $F_{\mathrm{v}} / F_{\mathrm{m}}$ and QPSII for Aphanizomenon sp., $N$. spumigena, and Nostoc sp. were demonstrated. It was found that fluorescence parameters of N. spumigena and Nostoc sp. were stimulated by adding the cell-free filtrate. On the other hand, the low concentrations stimulated fluorescence parameters of Aphanizomenon sp., while higher concentrations significantly inhibited the $F_{\mathrm{v}} / F_{\mathrm{m}}$ and $\Phi$ PSII.

Nan et al. [44] showed that the filtrate obtained from $U$. pertusa culture showed no inhibitory effect on the growth of seven microalgae species (Heterosigma akashiwo, Skeletonema costatum, Tetraselmis subcordiformis, Nitzschia closterium, Chaetoceros gracile, Isochrysis galbana, and Alexandrium tamarense). However, this filtrate addition strongly inhibited the growth of Chroomonas placoidea. Jin and Dong [30] also showed that single and multiple additions of $U$. pertusa filtrate had no inhibitory effect on the growth of two microalgae H. akashiwo and A. tamarense. On the other hand, Nakai et al. [31] showed that growth inhibition of 
the cyanobacterium M. aeruginosa by the macrophyte Myriophyllum spicatum required the continuous secretion of certain unstable growth-inhibiting allelopathic compounds. They also found that $M$. aeruginosa growth was not significantly inhibited after a single addition of allelopathic compounds, whereas multiple additions of metabolites from M. spicatum had an inhibitory effect on cyanobacterial growth. The same phenomena were also observed between the macroalgae Chara aspera and the green alga Scenedesmus acutus [45], where the reduction of $S$. acutus growth occurred only when C. aspera was actually present in the co-culture experiment. Jin and Dong [30] and Wang et al. [29] suggested that macroalgae from the genus Ulva releases rapidly decomposing allelopathic substances, and continuous allelochemical release from fresh thallus is necessary for effective inhibition of microalgal growth. Thus, the reported lack of effect of some concentrations of $U$. intestinalis filtrate on the cyanobacterial growth in our work may indicate that the amount of rapidly degradable allelopathic compounds released into the medium by this donor macroalgae was insufficient to detect a visible and significant response. Moreover, the increased potency of the extracts may also suggest that the allelopathic compounds in the cells were more concentrated than the portion released via cell-free filtrate into the environment.

The most common effect of allelopathic compounds produced by macroalgae and aquatic macrophytes recorded in the environment is the inhibition of growth of associated cyanobacterial and microalgal species (e.g., $[20,28])$. However, there are many mechanisms that may be responsible for stimulating or inhibiting the growth of target cyanobacteria by producing active metabolites by macroalgae into the environment. Inhibition of photosystem II (PSII) and changes in pigment content of target organisms by compounds secreted by macroalgae and aquatic macrophytes have been rarely studied in the literature. Körner and Nicklisch [11] studied the effects of the aquatic macrophytes M. spicatum, Ceratophyllum demersum, and Potamogeton pectinatus on photosynthesis of the cyanobacteria M. aeruginosa and Aphanizomenon sp. They showed inhibition of PS II in M. aeruginosa. PSII of the cyanobacterium Aphanizomenon sp. did not show changes under the influence of allelopathic compounds secreted by the tested macrophytes. Złoch et al. [46] studied the allelopathic activity of C. aspera, C. baltica and C. canescens on the fluorescence of the cyanobacterium Synechococcus sp. They showed that the photosynthetic parameters of the cyanobacterium were significantly changed. They found that after the first week of the experiment the photosynthetic values of Synechococcus sp. after the addition of the extract obtained from C. aspera were significantly lower than the control culture. A decrease in fluorescence was also noted in the case of $C$. baltica extracts. Only an extract concentration equal to $5 \mu \mathrm{L} \mathrm{mL} L^{-1}$ of C. baltica and C. canescens caused an increase in fluorescence for Synechococcus sp. after the seventh day of exposure. A detailed study on phytoplankton was also conducted by Prince et al. [47], who analyzed the effect of K. brevis on photosynthetic performance based on the fluorescence parameter $F_{\mathrm{v}} / F_{\mathrm{m}}$. The study showed that the target organisms (Akashiwo cf. sanguinea, Amphora sp., Asterionellopsis glacialis, P. minimum, and S. costatum) showed a decrease in photosynthetic efficiency after $1 \mathrm{~h}$ of exposure to the extract obtained from K. brevis. A strong decrease in PSII productivity as influenced by the addition of the extract was recorded in S. costatum, which was $68 \%$ compared to the control. Photosynthetic efficiency in Akashiwo cf. sanguinea, Amphora sp., A. glacialis, and P. minimum was inhibited between $19 \% 43 \%$ relative to the control. Moreover, the inhibition of photosynthetic efficiency by the extract obtained from K. brevis coincided with the negative effect on the growth of the target organisms tested. It is believed that measuring PSII efficiency can provide information on when target organisms are most susceptible to allelopathic effects. However, it is worth noting here that organic carbon sources including monosaccharide, disaccharide, oligosaccharide, and polysaccharides can be absorbed by microalgal [48-50] and cyanobacterial [51] cells, and this heterotrophic growth condition mostly influences chlorophyll contents $[48,52,53]$. Therefore, changed photosynthetic pigment contents and the maximum quantum yield of PSII photochemistry $\left(F_{\mathrm{v}} / F_{\mathrm{m}}\right)$ as well as the effective quantum yield of PSII photochemistry in cyanobacteria cells (TPSII) can be changed by the presence of available organic carbon sources [53]. Based on the obtained 
results, the present study demonstrated that the Baltic macroalgae affected photosynthetic pigment content and, thus, photosynthesis performance in target cyanobacteria, indicating a potential mechanism of action of the allelopathic compounds they produced. Reduction in photosynthetic pigment content and inhibition of PSII may result in lower primary production, resulting in slower growth rates of associated cyanobacterial species.

An interesting issue is the stimulation of the growth of Aphanizomenon sp. after addition of cell-free filtrate obtained from $U$. intestinalis. Stimulation of Aphanizomenon sp. growth under the influence of allelopathic compounds secreted by donor cyanobacteria was also reported by Śliwińska-Wilczewska et al. [54] and Konarzewska et al. [55]. Aphanizomenon sp. is known to create annual harmful blooms in the Baltic Sea [56]. It is possible that this cyanobacterium is capable of benefiting from allelochemicals produced by certain donor organisms. Such a skill would give Aphanizomenon sp. a competitive advantage over other Baltic cyanobacteria. This is a very interesting issue that requires further detailed research. On the other hand, the present study also showed that the addition of filtrate from $U$. intestinalis significantly inhibited the growth of N. spumigena and Nostoc sp. This indicates that the concentration of allelopathic compounds produced by Baltic $U$. intestinalis may be higher than that of marine and freshwater $U$. pertusa and U. lactuca investigated by Nan et al. [44], Jin and Dong [30], and Wang et al. [29]. The above-mentioned studies showed the possibility of secretion of unstable allelopathic compounds inhibiting the growth of selected organisms not only in freshwater and marine environments but also in brackish ecosystems.

\subsection{Effects of Ulva intestinalis on Cyanobacterial MC-LR and Phenol Content}

In this work, the effects of aqueous extract and cell-free filtrate concentrations obtained from $U$. intestinalis on the MC-LR and phenol content in target cyanobacteria cells were also demonstrated. It was shown that the addition of extract obtained from $U$. intestinalis caused a significant decrease in the MC-LR content in Nostoc sp. cells. Moreover, the addition of the filtrate also caused a slight decrease in the content of this toxin; however, it was not statistically significant. In our work we also demonstrated that that the addition of the extract from $U$. intestinalis had a positive effect on the cell-specific phenol content of all the examined cyanobacteria. Moreover, it was found that the addition of the cell-free filtrate obtained from $U$. intestinalis increased the phenol content in N. spumigena cells. The only exception was Aphanizomenon sp., where the cell-specific phenol content decreased due to the addition of the filtrate. Various factors can affect the MC [57] and phenol content of cyanobacterial cells [58]. In addition, $\mathrm{MC}$ is a known toxin affecting the ecosystem, from microalgae, zooplankton, fish, birds, and mammals [59]. In addition, people consume organisms that are capable of bioaccumulating MC, such as mussels, crayfish, crabs, or simply by drinking water directly contaminated with this toxin [59]. Phenols have been shown to negatively affect microbial activity for a number of different microorganisms [60-65], exemplifying the toxicity of such compounds. Furthermore, there are several toxic phenolic compounds that are on the priority pollutant list [66]. In cyanobacteria, MC and phenol content can be changed by manipulating different culture conditions [58,67]. In our work, we showed that $U$. intestinalis can modulate the content of harmful metabolites in cyanobacterial cells due to the production of allelopathic compounds. It is commonly known that selected cyanobacteria produce numerous secondary metabolites (e.g., [9,68-70]). Since demonstrating a number of chemical compounds on cyanobacteria produced by cyanobacteria requires thorough preparation and time-consuming experiments, we decided to select only two, but very important compounds. MC and phenols were selected as 'representatives' of the compounds, with a negative effect impact on coexisting plants and animals [2]. Moreover, MC-LR is listed as one of the most important algal toxins [71], that is especially harmful both for humans and animals. What is more, the bioaccumulation of MC in water organisms is documented [72], while phenol and its derivatives are one of the largest groups of environmental pollutants, that exhibit a wide range of biological effects, e.g., affecting both the activity of enzymes and photosynthetic processes of marine organisms [73]. 
Importantly, phenol due to its microbial toxicity accumulates in contaminated soils [74]. At this point we want to add that our research, focusing exclusively on MC and phenols, is particularly important both for the aquaculture production and environmental pollution. This research on selected cyanobacteria after exposure to macroalgal allelochemicals is pioneering and therefore definitely needs to be continued. We believe that the obtained results will be interesting for researchers and will contribute to the further development of research in this field.

\subsection{Ecological Significance of Allelopathic Effects of Baltic Macroalgae Ulva sp.}

Although macroalgal blooms are widespread and negatively impact many aquatic ecosystems, they have been largely neglected in biodiversity conservation research. The effects of macroalgal green algal blooms (commonly referred to as "green tide") are diverse and have been summarized by Fletcher [75] and Ansell et al. [76]. It is worth mentioning here that $U$. prolifera, the species causing the largest green tide in the world, is widely distributed in intertidal zones and estuaries worldwide due to its tolerance to a wide range of salinities and water temperatures, high growth rate and remarkable growth ability [77]. This species was also found in the Baltic Sea [78]. In a study conducted by $\mathrm{Xu}$ et al. [17] found that allelopathic compounds produced by $U$. prolifera can be actively released into the environment. In the study by Xu et al. [17] the highest concentration of $U$. prolifera was $3.75 \mathrm{~g}$ wet weight per liter of the culture. However, the authors noted that the effect of higher concentrations of $U$. prolifera should be investigated in the future, as higher concentrations may have a significant impact on the observed effects. In the present study, three concentrations were used to investigate the allelopathic effect for each of two experimental methods used. For the aqueous extract and filtrate-based experiments, 5, 25, and $50 \mu \mathrm{L} \mathrm{mL}{ }^{-1}$ were added to the target culture. Based on the results recorded in this study, it was found that the allelopathic effect of the extract stimulated the growth of tested cyanobacteria. The filtrate inhibited the growth of cyanobacteria N. spumigena and Nostoc sp. In contrast, the number of Aphanizomenon sp. cells was stimulated by the filtrate obtained from $U$. intestinalis. Generally, it was observed that the higher the concentration, the stronger the effect was obtained, confirming the observations of $\mathrm{Xu}$ et al. [17]. The present study may represent a significant advance in the study of ecological questions concerning the effects of green tides of Ulva sp. on cyanobacterial communities. It has been also demonstrated that $U$. intestinalis can produce a wide range of metabolites that have negative effects on other organisms. It has been shown that Ulva sp. may produce: penostatins A-H [79], cytochalasans, penochalasins A-H [80], chaetoglobosin [81], and communesins A-B [82]. Furthermore, based on previous studies conducted on Asian species belonging to Ulva, some of the allelopathic compounds produced by these green macroalgae may contain polyunsaturated fatty acids [83,84]. The work of Tang and Glober [28] also showed that the effect of concentrated extract of $U$. lactuca was as strong or even stronger than that of the filtrate, which is consistent with the hypothesis that polyunsaturated fatty acids may be active allelopathic agents. Hence, our next work will focus on the characterization of allelopathic compounds produced by the Baltic $U$. intestinalis responsible for stimulating and inhibiting the growth of bloom-forming cyanobacteria.

On the other hand, macroalgae belonging to the genus Ulva are widely distributed; thus, harvesting these macroalgae from shorelines provides an easy, economical and environmentally friendly way to potentially control the species responsible for creating massive blooms [19]. Jin et al. [43] in their work showed that two green algae, $U$. pertusa and $U$. linza, can secrete allelopathic substances that can inhibit the growth of Prorocentrum micans, which are known to create harmful blooms in the marine environment. Furthermore, Tang and Glober [28] showed that U. lactuca, through the secretion of allelopathic compounds, is able to limit the growth of seven phytoplankton species (Aureococcus anophagefferens, Chattonella marina, Cochlodinium polykrikoides, Karlodinium veneficum, K. brevis, P. minimum, and Pseudo-nitzschia multiseries) that are known to form massive blooms worldwide. However, it is worth emphasizing here that the application of allelopathic compounds for 
the control of cyanobacterial blooms may require their identification, which is largely difficult. Further research is also needed to clarify the mechanism of selective modes of action of allelopathic compounds against specific target organisms. Although it is possible to control algal growth under laboratory conditions, in natural ecosystems the effects of allelochemicals could be very different [31]. Therefore, more research should be conducted on the allelopathic activity of bioactive macroalgal metabolites on a wide range of target organisms in order to control cyanobacterial blooms in coastal areas in the future.

\section{Conclusions}

Although harmful properties are rarely associated with macroalgae, there is increasing evidence that some green macroalgae and their secondary metabolites have allelopathic properties [85]. In this study, we demonstrated that $U$. intestinalis effectively inhibits the growth of Baltic cyanobacteria Nodularia spumigena and Nostoc sp. Thus, the results obtained in this study provide new insight into the ecological role of macroalgae $U$. intestinalis in reducing the occurrence of certain massive bloom-forming cyanobacteria species in the Baltic Sea region. On the other hand, we also found positive allelopathic effects of $U$. intestinalis on other bloom-forming and toxic cyanobacterium Aphanizomenon sp. These results may indicate that in areas where there are underwater meadows and/or large biomass of $U$. intestinalis, may appear Aphanizomenon sp. in large quantities. Green macroalgae $U$. intestinalis are widely distributed and found in many aquatic ecosystems. Our results provide insight into the interactions between macroalgae and cyanobacteria in coastal areas and indicate the need to isolate and characterize allelopathic substances produced by Baltic green algae of the genus Ulva in the future. Chemical interactions between macroalgae and other organisms may play an important role in their dominance in coastal areas. Collection and processing of macroalgae biomass to predict and control Cyanobacterial Harmful Algal Blooms (CyanoHABs) [19] events would contribute to the development of the local economy.

\section{Materials and Methods}

\subsection{Material and Culture Conditions}

The experiment was conducted with the cyanobacteria Aphanizomenon sp. BA69, Nodularia spumigena BA15, and Nostoc sp. BA81 isolated from the southern Baltic Sea region (Figure 4). These strains were maintained as the non-axenic batch culture in the Culture Collection of Baltic Algae (CCBA) at the University of Gdańsk, Poland (http: //ccba.ug.edu.pl/pages/en/home.php, accessed on 20 August 2021).

Cyanobacterial strains $(\mathrm{V}=20 \mathrm{~mL})$ were maintained in $25-\mathrm{mL}$ glass Erlenmeyer flasks at $18{ }^{\circ} \mathrm{C}, 10 \mu \mathrm{mol}$ photons $\mathrm{m}^{-2} \mathrm{~s}^{-1}$ (16:8 h light:dark cycle), and salinity $7.5 \mathrm{psu}$. Experiments were conducted in incubators capable of maintaining constant temperature condition $\left( \pm 1^{\circ} \mathrm{C}\right)$. Fluorescent lamps (Cool White $40 \mathrm{~W}$, Sylvania, $\mathrm{OH}, \mathrm{USA}$ ) were used as a source of irradiance. The culture medium employed was $\mathrm{f} / 2$ [86] which have been prepared from water taken from the Baltic Sea with salinity of 7.5 psu and autoclaved. These growth conditions were used for both control and allelopathic experiments. The photosynthetically active radiation (PAR) was measured using a spherical quantum-meter (LI-COR, Lincoln, NE, USA). The salinity was verified by salinometer (inoLab Cond Level 1, Weilheim in Oberbayern, Germany).

$U$. intestinalis was selected based on the allelopathic potential of species from the genus Ulva [28-30,41]. This green macroalgae was collected manually from the coastal region of the southern Baltic Sea, Poland ( $54^{\circ} 31^{\prime} 08^{\prime \prime} \mathrm{N}$ and $\left.18^{\circ} 31^{\prime} 54^{\prime \prime} \mathrm{E}\right)$, immediately transported to the laboratory, and carefully washed with distilled water to remove attached organisms according to a method proposed by Mabrouk et al. [87]. In the next step, $U$. intestinalis was placed in a glass aquarium $(\mathrm{V}=6 \mathrm{~L})$ with the sterilized $\mathrm{f} / 2$ medium $(\mathrm{V}=5 \mathrm{~L})$ for two days. After that time, this $U$. intestinalis was taken to carry out allelopathic experiments (both for obtaining the extract and the cell-free filtrate). Determination of $U$. intestinalis was based on the examination of morphological features. Herbarium sheets were prepared in accordance 
with guidelines in Rybak [88]. Currently, the herbarium sheets were deposited at the Institute of Oceanography, University of Gdańsk, Poland and are available for inspection on the website (https:/ / zielnik.ug.edu.pl/en/home/ accessed on 20 August 2021).
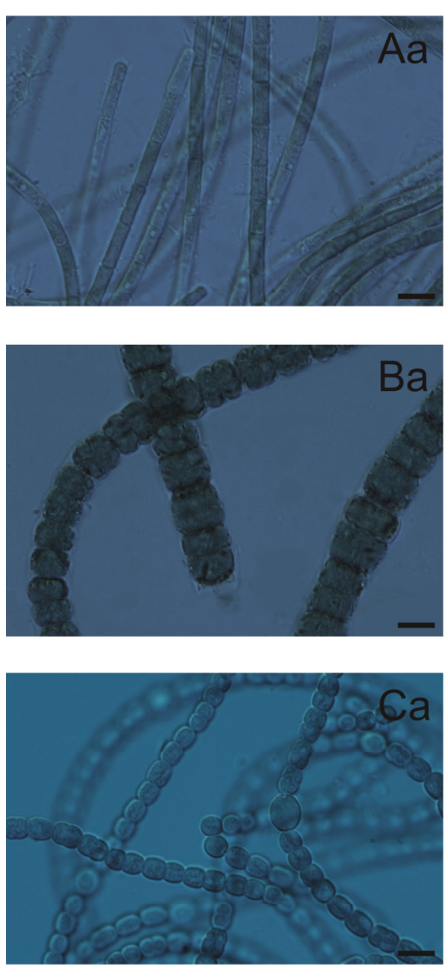
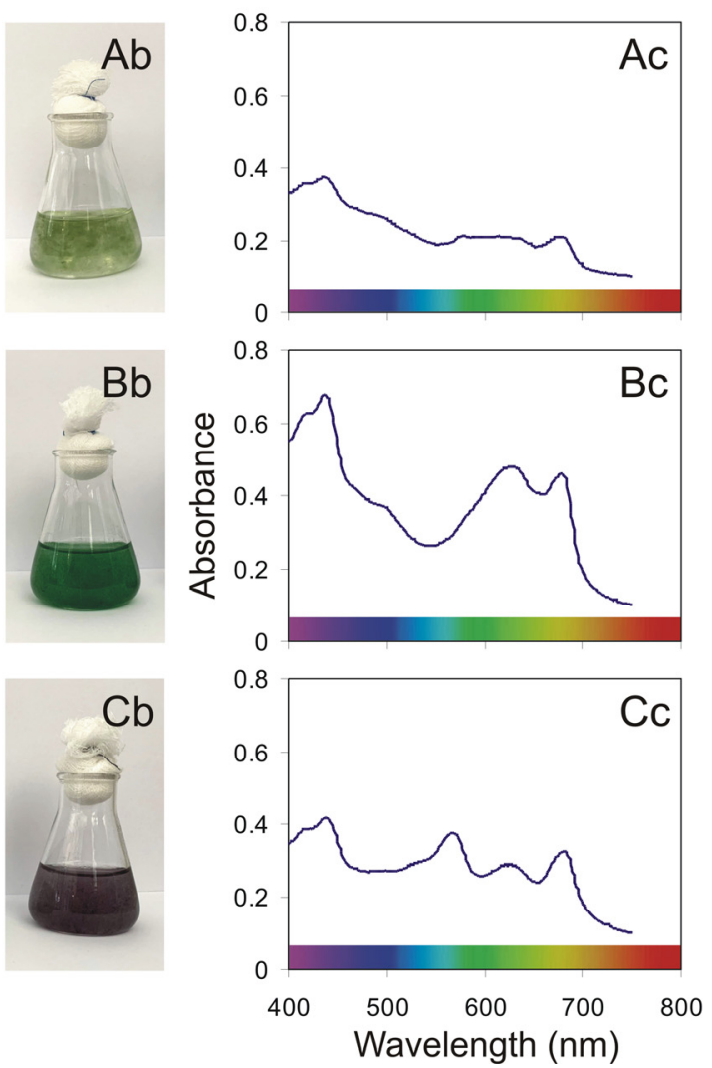

Figure 4. Light microscope photographs of Aphanizomenon sp. BA69 (A), N. spumigena BA15 (B), and Nostoc sp. BA81 (C). ((a); scale $=10 \mu \mathrm{m})$. photographs of the cyanobacterial culture in 25-mL glass flasks from the ex-perimental phase (b); and PAR absorption spectra determined for this strain at an optical density $(\mathrm{OD} 750)=0.1(\mathbf{c})$.

\subsection{Experimental Setup}

The allelopathic effects of $U$. intestinalis were tested according to a method proposed by Wang et al. [29] for cell-free filtrate additions and Złoch et al. [46] for aqueous extract addition. The cyanobacteria monocultures were exposed to three different concentrations of aqueous extracts and cell-free filtrate of $U$. intestinalis. All allelopathic tests were conducted in triplicate.

To prepare the aqueous extract, the air-dried materials were homogenized in a mortar grinding machine. For the bioassay experiment, $50 \mathrm{~g}$ of dried $U$. intestinalis was extracted with $20 \mathrm{~mL}$ of autoclaved $\mathrm{f} / 2$ medium for $10 \mathrm{~min}$. The aqueous extract of $U$. intestinalis was filtered through glass fiber filters (Whatman GF/C, Saint Louis, MO, USA) using a vacuum pump ( 0.5 bar). Sterilized Erlenmeyer flasks $(\mathrm{V}=25 \mathrm{~mL})$ contained $20 \mathrm{~mL}$ of $\mathrm{f} / 2$ medium with target cyanobacteria strains (initial inoculum was $10^{5}$ cells $\mathrm{mL}^{-1}$ ) and different volumes of macroalgae extract treatments. Experimental treatments were prepared by adding 100,500 and $1000 \mu \mathrm{L}$ of $U$. intestinalis extracts to $25 \mathrm{~mL}$ Erlenmeyer flasks containing $20 \mathrm{~mL}$ of cell suspensions of the targeted cyanobacteria (the final concentrations of extract were: 5,25 , and $50 \mu \mathrm{L} \mathrm{mL}^{-1}$ ). Controls consisted of the addition of 100, 500 and $1000 \mu \mathrm{L}$ of filtrated f/ 2 medium to $25 \mathrm{~mL}$ Erlenmeyer flasks containing $20 \mathrm{~mL}$ of the same cyanobacteria strains. The flasks with cyanobacteria were gently swirled once a day.

To prepare the cell-free filtrate, a different concentration of $\mathrm{f} / 2$ medium in which $U$. intestinalis was grown for 3 days in Erlenmeyer flasks $(V=250 \mathrm{~mL})$ at a concentration of $80 \mathrm{~g}$ wet weight $\mathrm{L}^{-1}$ was added. This filtrate was enriched with nutrients equivalent to the 
f/2 medium and filtered through a membrane filter (Whatman GF/C, Saint Louis, MO, USA). Treatments were prepared by adding 100,500 and $1000 \mu \mathrm{L}$ of $U$. intestinalis exudates to $20 \mathrm{~mL}$ of target cyanobacteria. Initial inoculum of cyanobacteria strains was $10^{5}$ cells $\mathrm{mL}^{-1}$ and the final concentrations of cell-free filtrate were: 5,25 , and $50 \mu \mathrm{L} \mathrm{mL}^{-1}$. Controls consisted of the addition of 100,500 and $1000 \mu \mathrm{L}$ of filtrated $\mathrm{f} / 2$ medium to $20 \mathrm{~mL}$ of the same target cyanobacteria strains. The flasks with cyanobacteria were gently swirled once a day.

\subsection{Determination of the Culture Density}

Cell densities in the cyanobacteria cultures were estimated with previously determined linear regression models between the optical density (OD) and the number of cells $\left(\mathrm{N} \mathrm{mL}^{-1}\right)$ following a procedure according to Śliwińska-Wilczewska et al. [54] for Aphanizomenon sp. and Nostoc sp. and Barreiro Felpeto et al. [89] for N. spumigena. N was counted using a Bürker chamber [90]. OD was measured spectrophotometrically at $750 \mathrm{~nm}$ with a Multiskan GO UV-VIS spectrophotometer (Thermo Scientific, Waltham, MA, USA). Cyanobacterial cell densities were examined for control and experiments with aqueous extract and cell-free filtrate from $U$. intestinalis additions after 7 and 14 days of the experiment.

\subsection{Determination of the Pigments Content}

The Chl $a$ and Car content of analyzed cyanobacteria were measured by the spectrophotometric method [54]. After 7 days of incubation, $15 \mathrm{~mL}$ of culture was filtered using membrane filters (Whatman GF/C, Saint Louis, MO, USA) to separate the cyanobacteria cells from the medium. Chl $a$ and Car were extracted from the cyanobacteria cells with $90 \%$ acetone $(\mathrm{V}=2 \mathrm{~mL})$. The pigment extract was held in the dark for $2 \mathrm{~h}$ at $-20{ }^{\circ} \mathrm{C}$ and centrifuged at 12,000 rpm for $2 \mathrm{~min}$ to remove filter particles (Sigma 2-16P, Osterode am Harz, Germany). The extinction was determined with a Thermo Scientific UV-VIS Multiscan GO spectrophotometer (Thermo Scientific, Waltham, MA, USA) using a $1 \mathrm{~cm}$ glass cuvette. The concentrations of $\mathrm{Chl} a$ and Car were calculated according to Strickland and Parsons [91] with the formula: $\mathrm{Chl} a\left(\mu \mathrm{g} \mathrm{mL} \mathrm{L}^{-1}\right)=11.236\left(\mathrm{~A}_{665}-\mathrm{A}_{750}\right) \mathrm{V}_{\mathrm{a}} / \mathrm{V}_{\mathrm{b}}$, and $\operatorname{Car}\left(\mu \mathrm{g} \mathrm{mL}^{-1}\right)=4\left(\mathrm{~A}_{480}-\mathrm{A}_{750}\right) \mathrm{V}_{\mathrm{a}} / \mathrm{V}_{\mathrm{b}}$, where: $\mathrm{V}_{\mathrm{a}}$ - extract volume $(\mathrm{mL})$ and $\mathrm{V}_{\mathrm{b}}$-sample volume $(\mathrm{mL})$. $\mathrm{A}_{\mathrm{n}}$-absorption at a specific wavelength; ${ }_{\mathrm{n}}$ - wavelength (nm).

\subsection{Measurements of the Photosynthesis Performance}

Chlorophyll $a$ fluorescence was measured using PAM method by a fluorometer (FMS1, Hansatech, King's Lynn, UK) according to the method described by Złoch et al. [46]. Tested cyanobacteria were taken for chlorophyll fluorescence analysis after the 7th day of the experiment. The maximum quantum yield of PSII photochemistry in cyanobacterial cells was obtained as $F_{\mathrm{v}} / F_{\mathrm{m}}$ by measuring the maximum fluorescence $\left(F_{\mathrm{m}}\right)$ and minimum fluorescence $\left(F_{0}\right): F_{\mathrm{v}} / F_{\mathrm{m}}=\left(F_{\mathrm{m}}-F_{0}\right) F_{\mathrm{m}}{ }^{-1}$, where $F_{\mathrm{m}}$ and $F_{0}$ are the maximum and minimum fluorescence in dark-adapted cells, respectively. The effective quantum yield of PSII photochemistry in cyanobacteria cells was obtained as $\Phi P S I I$ by measuring the maximal fluorescence in the light-adapted state $\left(F_{\mathrm{m}^{\prime}}\right)$ and steady-state fluorescence $\left(F_{\mathrm{s}}\right)$ : ФPSII $=\left(F_{\mathrm{m}^{\prime}}-F_{\mathrm{s}}\right) F_{\mathrm{m}^{\prime}}{ }^{-1}[92]$.

\subsection{Measurements of the Microcystin and Phenol Content}

ELISA quantitation for microcystin-LR (MC-LR) equivalents was performed using a Microcystin-LR ELISA kit (colorimetric) (Abnova, Taipei, Taiwan) as per the manufacturer's specifications [93]. Final absorbances were read at $450 \mathrm{~nm}$ in triplicates using a Thermo Scientific Multiscan Go microplate reader (Thermo Scientific, Waltham, MA, USA). Target cyanobacteria were taken for MC-LR analysis after the 7th day of the experiment for controls and allelopathic treatment with the additions of $50 \mu \mathrm{L} \mathrm{mL} L^{-1}$ of extracts and cell-free filtrate from $U$. intestinalis.

Phenols were quantified in the liquid phase by using a cuvette test $(0.05-5.0 \mathrm{mg} / \mathrm{L}$, 24 tests) from Hach Lange (LCK 346 Phenols, Hach Lange, Düsseldorf, Germany) according 
to the manufacturer's specifications [94]. In this method, phenols react with 4-nitroaniline to form a yellow color complex, which was measured in a Thermo Scientific Multiscan Go microplate reader (Thermo Scientific, Waltham, MA, USA). The effects of $50 \mu \mathrm{L} \mathrm{mL}^{-1}$ of extract and cell-free filtrate concentrations obtained from $U$. intestinalis after the 7 th day of the expositions on the phenol content in target cyanobacteria cells were determined.

\subsection{Statistical Analyses}

One-way ANONA was applied to determine whether the growth of the analyzed cyanobacteria Aphanizomenon sp. BA69, Nodularia spumigena BA15, and Nostoc sp. BA81 (after 7 and 14 day of the experiment), pigment content ( $\mathrm{Chl} a$ and $\mathrm{Car}$ ) and fluorescence parameters $\left(F_{\mathrm{V}} / F_{\mathrm{m}}\right.$ and $\Phi$ PSII) when treated with different concentration of the extracts and cell-free filtrate of $U$. intestinalis differed from the control and the experiments. Oneway ANOVA was also used to determine whether the MC and phenol content of the target cyanobacteria species, when treated with green macroalgae extracts and cell-free filtrate, differed from the control on the last day of the experiment. Data are reported as the means \pm standard deviations, where level of significance was $p<0.05$. Statistical analysis and graphs were created with the program OriginPro, Version 2021 (OriginLab Corporation, Northampton, MA, USA).

Supplementary Materials: The following are available online at https: / www.mdpi.com/article / 10.3390 / toxins13080589/s1, Figure S1: Phenol concentration $\left(\mathrm{mg} \mathrm{L}^{-1}\right)$ of Aphanizomenon sp. BA69 (A), N. spumigena BA15 (B), and Nostoc sp. BA81 (C) for controls (c) and treatments of extract (e), and cell-free filtrate (f) additions obtained from macroalgae $U$. intestinalis after 7 days of the expositions, Table S1: MC-LR $\left(\mu \mathrm{g} \mathrm{L}^{-1}\right)$ and phenol content $\left(\mathrm{mg} \mathrm{L}^{-1}\right)$ for Aphanizomenon sp. BA69 (A), N. spumigena BA15 (B), and Nostoc sp. BA81 (C) for controls and treatments after the extract and cell-free filtrate additions obtained from macroalgae $U$. intestinalis after 7 days of the expositions.

Author Contributions: Conceptualization, G.B. and S.S.-W.; methodology, G.B. and S.Ś.-W.; software, G.B., M.K. and S.Ś.-W.; validation, G.B. and S.Ś.-W.; formal analysis, G.B.; investigation, G.B.; resources, G.B.; data curation, S.Ś.-W. and K.W.; writing-original draft preparation, G.B., S.Ś.-W., M.K., K.W., A.L. and J.M.W.; visualization, S.S.-W. and M.K.; supervision, A.L. and J.M.W. All authors have read and agreed to the published version of the manuscript.

Funding: This research was funded by UGrants-bridge, grant number 533-O000-GB004-21. The APC was funded by UGrants-bridge No. 533-O000-GB004-21.

Institutional Review Board Statement: Not applicable.

Informed Consent Statement: Not applicable.

Data Availability Statement: All data are presented in the article and Supplementary Materials.

Acknowledgments: The authors would like to thank the Editor and anonymous Reviewers for their valuable comments and suggestions to improve the quality of the paper.

Conflicts of Interest: The authors declare no conflict of interest. The funders had no role in the design of the study; in the collection, analyses, or interpretation of data; in the writing of the manuscript, or in the decision to publish the results.

\section{References}

1. Granéli, E.; Salomon, P.S.; Fistarol, G.O. The role of allelopathy for harmful algae bloom formation. In Algal Toxins: Nature, Occurrence, Effect and Detection; Springer: Dordrecht, The Netherlands, 2008; pp. 159-178.

2. Leflaive, J.; Ten-Hage, L. Algal and cyanobacterial secondary metabolites in freshwaters: A comparison of allelopathic compounds and toxins. Freshw. Biol. 2007, 52, 199-214. [CrossRef]

3. Lewis, W.M., Jr. Evolutionary interpretations of allelochemical interactions in phytoplankton algae. Am. Nat. 1986, 127, 184-194. [CrossRef]

4. Igarashi, T.; Oshima, Y.; Murata, M.; Yasumoto, T. Chemical studies on prymnesins isolated from Prymnesium parvum. In Harmful Marine Algal Blooms: Proceedings of the Sixth International Conference on Toxic Marine Phytoplankton; Lassus, P., Arzul, G., Erard-Le-Denn, E., Gentien, P., Marcaillou-Le-Baut, C., Eds.; Lavoisier: Paris, France, 1995; pp. 303-308. 
5. Igarashi, T.; Satake, M.; Yasumoto, T. Structures and partial stereochemical assignments for prymnesin-1 and prymnesin-2: Potent hemolytic and ichthyotoxic glycosides isolated from the red tide alga Prymnesium parvum. J. Am. Chem. Soc. 1999, 121, 8499-8511. [CrossRef]

6. Von Elert, E.; Jüttner, F. Phosphorus limitation and not light controls the extracellular release of allelopathic compounds by Trichormus doliolum (Cyanobacteria). Limnol. Oceanogr. 1997, 42, 1796-1802. [CrossRef]

7. Smith, G.D.; Doan, N.T. Cyanobacterial metabolites with bioactivity against photosynthesis in cyanobacteria, algae, and higher plants. J. Appl. Phycol. 1999, 11, 337-344. [CrossRef]

8. Legrand, C.; Rengefors, K.; Fistarol, G.O.; Graneli, E. Allelopathy in phytoplankton-biochemical, ecological and evolutionary aspects. Phycologia 2003, 42, 406-419. [CrossRef]

9. Śliwińska-Wilczewska, S.; Wiśniewska, K.; Konarzewska, Z.; Cieszyńska, A.; Felpeto, A.B.; Lewandowska, A.U.; Latała, A. The current state of knowledge on taxonomy, modulating factors, ecological roles, and mode of action of phytoplankton allelochemicals. Sci. Total Environ. 2021, 773, 145681. [CrossRef]

10. Rodríguez-Ramos, T.; Lorenzo, P.; González, L. Marine Allelopathy: Principles and perspectives. Thalassas 2007, $23,39-49$.

11. Körner, S.; Nicklisch, A. Allelopathic growth inhibition of selected phytoplankton species by submerged macrophytes1. J. Phycol. 2002, 38, 862-871. [CrossRef]

12. Leu, E.; Krieger-Liszkay, A.; Goussias, C.; Gross, E.M. Polyphenolic allelochemicals from the aquatic angiosperm Myriophyllum spicatuminhibit photosystem II. Plant Physiol. 2002, 130, 2011-2018. [CrossRef]

13. Gross, E.M. Allelopathy of aquatic autotrophs. Crit. Rev. Plant Sci. 2003, 22, 313-339. [CrossRef]

14. Hilt, S. Allelopathic inhibition of epiphytes by submerged macrophytes. Aquat. Bot. 2006, 85, 252-256. [CrossRef]

15. Hilt, S.; Ghobrial, M.G.; Gross, E.M. In situ allelopathic potential of Myriophyllum verticillatum (haloragaceae) against selected phytoplankton species. J. Phycol. 2006, 42, 1189-1198. [CrossRef]

16. Gross, E. Allelopathy in benthic and littoral areas: Case studies on allelochemicals from benthic cyanobacteria and submersed macrophytes. In Principles and Practices in Plant Ecology; Dakshini, I.K.M.M., Foy, C.L., Eds.; CRC Press: Boca Raton, FL, USA, 1999; pp. 179-199.

17. Xu, D.; Gao, Z.; Zhang, X.; Fan, X.; Wang, Y.; Li, D.; Wei, W.; Zhimeng, Z.; Ye, N. Allelopathic interactions between the opportunistic species Ulva prolifera and the native macroalga Gracilaria lichvoides. PLoS ONE 2012, 7, e33648. [CrossRef]

18. Harlin, M.M.; Rice, E.L. Allelochemistry in marine macroalgae. Crit. Rev. Plant Sci. 1987, 5, 237-249. [CrossRef]

19. Jeong, J.H.; Jin, H.J.; Sohn, C.H.; Suh, K.H.; Hong, Y.K. Algicidal activity of the seaweed Corallina pilulifera against red tide microalgae. J. Appl. Phycol. 2000, 12, 37-43. [CrossRef]

20. Gross, E.M.; Erhard, D.; Iványi, E. Allelopathic activity of Ceratophyllum demersum L. and Najas marina ssp. intermedia (Wolfgang) Casper. Hydrobiologia 2003, 506, 583-589. [CrossRef]

21. Dodds, W.K. Community interactions between the filamentous alga Cladophora glomerata (L.) Kuetzing, its epiphytes, and epiphyte grazers. Oecologia 1991, 85, 572-580. [CrossRef]

22. Anthoni, U. Biologically active sulphur compounds from the green alga Chara globularis. Phytochemistry 1980, 19, 1228-1229. [CrossRef]

23. Anthoni, U.; Nielsen, P.H.; Smith-Hansen, L.; Wium-Andersen, S.; Christophersen, C. Charamin, a quaternary ammonium ion antibiotic from the green alga Chara globularis. J. Org. Chem. 1987, 52, 694-695. [CrossRef]

24. Wium-Andersen, S.; Anthoni, U.; Christophersen, C.; Houen, G. Allelopathic effects on phytoplankton by substances isolated from aquatic macrophytes (Charales). Oikos 1982, 39, 187-190. [CrossRef]

25. Wium-Andersen, S.; Anthoni, U.; Houen, G. Elemental sulphur, a possible allelopathic compound from Ceratophyllum demersum. Phytochemistry 1983, 22, 2613. [CrossRef]

26. Mulderij, G.; van Donk, E.; Roelofs, J.G.M. Differential sensitivity of green algae to allelopathic substances from Chara. Hydrobiologia 2003, 491, 261-271. [CrossRef]

27. Hootsmans, M.J.M.; Blindow, I. Allelopathic limitation of algal growth by macrophytes. In Lake Veluwe A Macrophyte-Domin. Syst. Under Eutrophication Stress; Springer: Dordrecht, The Netherlands, 1994; pp. 175-192.

28. Tang, Y.Z.; Gobler, C.J. The green macroalga, Ulva lactuca, inhibits the growth of seven common harmful algal bloom species via allelopathy. Harmful Algae 2011, 10, 480-488. [CrossRef]

29. Wang, R.; Xiao, H.; Zhang, P.; Qu, L.; Cai, H.; Tang, X. Allelopathic effects of Ulva pertusa, Corallina pilulifera and Sargassum thunbergii on the growth of the dinoflagellates Heterosigma akashiwo and Alexandrium tamarense. J. Appl. Phycol. 2007, 19, 109-121. [CrossRef] [PubMed]

30. Jin, Q.; Dong, S. Comparative studies on the allelopathic effects of two different strains of Ulva pertusa on Heterosigma akashiwo and Alexandrium tamarense. J. Exp. Mar. Biol. Ecol. 2003, 293, 41-55. [CrossRef]

31. Nakai, S.; Inoue, Y.; Hosomi, M.; Murakami, A. Growth inhibition of blue- green algae by allelopathic effects of macrophytes. Water Sci. Technol. 1999, 39, 47. [CrossRef]

32. Xian, Q.; Chen, H.; Zou, H.; Yin, D. Allelopathic activity and nutrients competition between Ceratophyllum demersum and Microcystis aeruginosa. In Proceedings of the 4th World Congress on Allelopathy, "Establishing the Scientific Base", Centre for Rural Social Research, Charles Sturt University, Wagga Wagga, NSW, Australia, 21-26 August 2005; pp. $403-406$.

33. Mulderij, G.; Mooij, W.M.; Donk, E.V. Allelopathic growth inhibition and colony formation of the green alga Scenedesmus obliquus by the aquatic macrophyte Stratiotes aloides. Aquat. Ecol. 2005, 39, 11-21. [CrossRef] 
34. Mulderij, G.; Mau, B.; van Donk, E.; Gross, E.M. Allelopathic activity of Stratiotes aloides on phytoplankton- towards identification of allelopathic substances. Hydrobliologia 2007, 584, 89-100. [CrossRef]

35. Bauer, N.; Blaschke, U.; Beutler, E.; Gross, E.M.; Jenett-Siems, K.; Siems, K.; Hilt, S. Seasonal and interannual dynamics of polyphenols in Myriophyllum verticillatum and their allelopathic activity on Anabaena variabilis. Aquat. Bot. 2009, 91, 110-116. [CrossRef]

36. Zhu, J.; Liu, B.; Wang, J.; Gao, Y.; Wu, Z. Study on the mechanism of allelopathic influence on cyanobacteria and chlorophytes by submerged macrophyte (Myriophyllum spicatum) and its secretion. Aquat. Toxicol. 2010, 98, 196-203. [CrossRef]

37. Ghobrial, M.G.; Nassr, H.S.; Kamil, A.W. Bioactivity effect of two macrophyte extracts on growth performance of two bloomforming cyanophytes. Egypt. J. Aquat. Res. 2015, 41, 69-81. [CrossRef]

38. Pełechata, A.; Pełechaty, M. The in-situ influence of Ceratophyllum demersum on a phytoplankton assemblage. Oceanol. Hydrobiol. Stud. 2010, 39, 95-101. [CrossRef]

39. Aliotta, G.; Della Greca, M.; Monaco, P.; Pinto, G.; Pollio, A.; Previtera, L. In vitro algal growth inhibition by phytotoxins of Typha latifolia L. J. Chem. Ecol. 1990, 16, 2637-2646. [CrossRef]

40. Erhard, D.; Gross, E.M. Allelopathic activity of Elodea canadensis and Elodea nuttallii against epiphytes and phytoplankton. Aquat. Bot. 2006, 85, 203-211. [CrossRef]

41. Dineshkumar, R.; Narendran, R.; Sampathkumar, P. Cultivation of Spirulina platensis in different selective media. Indian J. Mar. Sci. 2016, 45, 1749-1754.

42. Sánchez-Bayo, A.; Morales, V.; Rodríguez, R.; Vicente, G.; Bautista, L.F. Cultivation of microalgae and cyanobacteria: Effect of operating conditions on growth and biomass composition. Molecules 2020, 25, 2834. [CrossRef] [PubMed]

43. Jin, Q.; Dong, S.; Wang, C. Allelopathic growth inhibition of Prorocentrum micans (Dinophyta) by Ulva pertusa and Ulva linza (Chlorophyta) in laboratory cultures. Eur. J. Phycol. 2005, 40, 31-37. [CrossRef]

44. Nan, C.; Zhang, H.; Zhao, G. Allelopathic interactions between the macroalga Ulva pertusa and eight microalgal species. J. Sea Res. 2004, 52, 259-268. [CrossRef]

45. Van Donk, E.; van de Bund, W.J. Impact of submerged macrophytes including charophytes on phyto-and zooplankton communities: Allelopathy versus other mechanisms. Aquat. Bot. 2002, 72, 261-274. [CrossRef]

46. Złoch, I.; Śliwińska-Wilczewska, S.; Kucharska, M.; Kozłowska, W. Allelopathic effects of Chara species (C. aspera, C. baltica, and C. canescens) on the bloom-forming picocyanobacterium Synechococcus sp. Environ. Sci. Pollut. Res. 2018, 25, 36403-36411. [CrossRef]

47. Prince, E.K.; Myers, T.L.; Kubanek, J. Effects of harmful algal blooms on competitors: Allelopathic mechanisms of the red tide dinoflagellate Karenia brevis. Limnol. Oceanogr. 2008, 53, 531-541. [CrossRef]

48. Ceron, G.M.; Camacho, F.G.; Mirón, A.S.; Sevilla, J.M.; Chisti, Y.; Grima, E.M. Mixotrophic production of marine microalga Phaeodactylum tricornutum on various carbon sources. J. Microbiol. Biotechnol. 2006, 16, 689-694.

49. Tanoi, T.; Kawachi, M.; Watanabe, M.M. Effects of carbon source on growth and morphology of Botryococcus braunii. J. Appl. Phycol. 2011, 23, 25-33. [CrossRef]

50. Da Silva Ferreira, V.; Sant'Anna, C. Impact of culture conditions on the chlorophyll content of microalgae for biotechnological applications. World J. Microbiol. Biotechnol. 2017, 33, 1-8. [CrossRef]

51. Noaman, N.H.; Fattah, A.; Khaleafa, M.; Zaky, S.H. Factors affecting antimicrobial activity of Synechococcus leopoliensis. Microbiol. Res. 2004, 159, 395-402. [CrossRef] [PubMed]

52. Cheirsilp, B.; Torpee, S. Enhanced growth and lipid production of microalgae under mixotrophic culture condition: Effect of light intensity, glucose concentration and fed-batch cultivation. Bioresour. Technol. 2012, 110, 510-516. [CrossRef]

53. Gim, G.H.; Ryu, J.; Kim, M.J.; Kim, P.I.; Kim, S.W. Effects of carbon source and light intensity on the growth and total lipid production of three microalgae under different culture conditions. J. Ind. Microbiol. Biotechnol. 2016, 43, 605-616. [CrossRef] [PubMed]

54. Śliwińska-Wilczewska, S.; Maculewicz, J.; Barreiro Felpeto, A.; Vasconcelos, V.; Latała, A. Allelopathic activity of the picocyanobacterium Synechococcus sp. on filamentous cyanobacteria. J. Exp. Mar. Biol. Ecol. 2017, 496, 16-21. [CrossRef]

55. Konarzewska, Z.; Śliwińska-Wilczewska, S.; Barreiro Felpeto, A.; Vasconcelos, V.; Latała, A. Assessment of allelochemical activity and biochemical profile of different phenotypes of picocyanobacteria from the genus Synechococcus. Mar. Drugs 2020, 18, 179. [CrossRef]

56. Ploug, H. Cyanobacterial surface blooms formed by Aphanizomenon sp. and Nodularia spumigena in the Baltic Sea: Small-scale fluxes, pH, and oxygen microenvironments. Limnol. Oceanogr. 2008, 53, 914-921. [CrossRef]

57. Graham, J.L.; Jones, J.R.; Jones, S.B.; Downing, J.A.; Clevenger, T.E. Environmental factors influencing microcystin distribution and concentration in the Midwestern United States. Water Res. 2004, 38, 4395-4404. [CrossRef] [PubMed]

58. Blagojević, D.; Babić, O.; Rašeta, M.; Šibul, F.; Janjušević, L.; Simeunović, J. Antioxidant activity and phenolic profile in filamentous cyanobacteria: The impact of nitrogen. J. Appl. Phycol. 2018, 30, 2337-2346. [CrossRef]

59. De Figueiredo, D.R.; Azeiteiro, U.M.; Esteves, S.M.; Gonçalves, F.J.; Pereira, M.J. Microcystin-producing blooms-A serious global public health issue. Ecotoxicol. Environ. Saf. 2004, 59, 151-163. [CrossRef] [PubMed]

60. Varel, V.H.; Miller, D.N. Plant-derived oils reduce pathogens and gaseousemissions from stored cattle waste. Appl. Environ. Microbiol. 2001, 67, 1366-1370. [CrossRef]

61. Olguin-Lora, P.; Puig-Grajales, L.; Razo-Flores, E. Inhibition of the acetoclastic methanogenic activity by phenol and alkyl phenols. Environ. Technol. 2003, 24, 999-1006. [CrossRef] 
62. Levén, L.; Nyberg, K.; Korkea-Aho, L.; Schnürer, A. Phenols in anaerobic digestion processes and inhibition of ammonia oxidising bacteria (AOB) in soil. Sci. Total Environ. 2006, 364, 229-238. [CrossRef]

63. Dyreborg, S.; Arvin, E. Inhibition of nitrification by creosote-contaminated water. Water Res. 1995, 29, 1603-1606. [CrossRef]

64. Hernandez, J.E.; Edyvean, R.G.J. Inhibition of biogas production and biodegradability by substituted phenolic compounds in anaerobic sludge. J. Hazard. Mater. 2008, 160, 20-28. [CrossRef]

65. Levén, L.; Nyberg, K.; Schnürer, A. Conversion of phenols during anaerobic digestion of organic solid waste-a review of important microorganisms and impact of temperature. J. Environ. Manag. 2012, 95, S99-S103. [CrossRef]

66. Alonso, M.C.; Puig, D.; Silgoner, I.; Grasserbauer, M.; Barcelo, D. Determination of priority phenolic compounds in soil samples by various extraction methods followed by liquid chromatography-atmospheric pressure chemical ionisation mass spectrometry. J. Chromatogr. A 1998, 823, 231-239. [CrossRef]

67. Pimentel, J.S.; Giani, A. Microcystin production and regulation under nutrient stress conditions in toxic Microcystis strains. Appl. Environ. Microbiol. 2014, 80, 5836-5843. [CrossRef]

68. Codd, G.A.; Bell, S.G.; Brooks, W.P. Cyanobacterial toxins in water. Water Sci. Technol. 1989, 21, 1-13. [CrossRef]

69. Codd, G.A.; Ward, C.J.; Bell, S.G. Cyanobacterial toxins: Occurrence, modes of action, health effects and exposure routes. J. Appl. Toxicol. 1997, 399-410.

70. Puschner, B. Cyanobacterial (blue-green algae) toxins. In Veterinary Toxicology; Academic Press: Cambridge, MA, USA, 2018; pp. 763-777.

71. Mekebri, A.; Blondina, G.J.; Crane, D.B. Method validation of microcystins in water and tissue by enhanced liquid chromatography tandem mass spectrometry. J. Chromatogr. A 2009, 1216, 3147-3155. [CrossRef]

72. Ibelings, B.W.; Chorus, I. Accumulation of cyanobacterial toxins in freshwater "seafood" and its consequences for public health: A review. Environ. Pollut. 2007, 150, 177-192. [CrossRef] [PubMed]

73. Żyszka-Haberecht, B.; Niemczyk, E.; Lipok, J. Metabolic relation of cyanobacteria to aromatic compounds. Appl. Microbiol. Biotechnol. 2019, 103, 1167-1178. [CrossRef] [PubMed]

74. Watson, C.; Bahadur, K.; Briess, L.; Dussling, M.; Kohler, F.; Weinsheimer, S.; Wichern, F. Mitigating negative microbial effects of p-nitrophenol, phenol, copper and cadmium in a sandy loam soil using biochar. Water Air Soil Pollut. 2017, 228, 74. [CrossRef]

75. Fletcher, R.L. The occurrence of "green tides"—A review. Mar. benthic Veg. 1996, 123, 7-43.

76. Ansell, A.; Gibson, R.; Barnes, M.; Press, U. Ecological impact of green macroalgal blooms. Oceanogr. Mar. Biol. Annu. Rev. 1998, $36,97-125$.

77. Zhang, X.; Xu, D.; Mao, Y.; Li, Y.; Xue, S.; Zou, J.; Lian, W.; Liang, C.; Zhuang, Z.; Wang, Q.; et al. Settlement of vegetative fragments of Ulva prolifera confirmed as an important seed source for succession of a large-scale green tide bloom. Limnol. Oceanogr. 2001, 56, 233-242. [CrossRef]

78. Snoeijs-Leijonmalm, P.; Schubert, H.; Radziejewska, T. Biological Oceanography of the Baltic Sea; Springer Science \& Business Media: Dordrecht, The Netherlands, 2017.

79. Takahashi, C.; Numata, A.; Yamada, T.; Minoura, K.; Enomoto, S.; Konishi, K.; Nakai, M.; Matsuda, C.; Nomoto, K. Penostatins, novel cytotoxic metabolites from a Penicillium species separated from a green alga. Tetrahedron Lett. 1997, 37, 655-658. [CrossRef]

80. Numata, A.; Takahashi, C.; Ito, Y.; Minoura, K.; Yamada, T.; Matsuda, C.; Nomoto, K. Penochalasins, a novel class of cytotoxic cytochalasans from a Penicillium species separated from a marine alga: Structure determination and solution conformation. $J$. Chem. Soc. Perkin Trans. 1996, 1, 239-245. [CrossRef]

81. Iwamoto, C.; Yamada, T.; Ito, Y.; Minoura, K.; Numata, A. Cytotoxic cytochalasans from a Penicillium species separated from a marine alga. Tetrahedron 2001, 57, 2904-2997. [CrossRef]

82. Numata, A.; Takahashi, C.; Ito, Y.; Takeda, T.; Kawai, K.; Osami, Y.; Matsumura, E.; Imachi, M.; Ito, T.; Hasegawa, T. Communesins, cytotoxic metabolites of a fungus isolated from a marine alga. Tetrahedron Lett. 1996, 34, 2355-2358. [CrossRef]

83. Alamsjah, M.A.; Hirao, S.; Ishibashi, F.; Fujita, Y. Isolation and structure determination of algicidal compounds from Ulva fasciata. Biosci. Biotechnol. Biochem. 2005, 69, 2186-2192. [CrossRef]

84. Alamsjah, M.A.; Hirao, S.; Ishibashi, F.; Oda, T.; Fujita, Y. Algicidal activity of polyunsaturated fatty acids derived from Ulva fasciata and U. pertusa (Ulvaceae, Chlorophyta) on phytoplankton. Ninet. Int. Seaweed Symp. 2007, 2, $263-270$.

85. Nelson, T.A.; Lee, D.; Smith, B.C.; Prins, R. Are 'Green tides' Harmful Algal Blooms? Allelopathic Properties of Extracts from Ulva fenestrata and Ulvaria obscura. J. Phycol. 2002, 38, 28-29. [CrossRef]

86. Guillard, R.R.L. Culture of phytoplankton for feeding marine invertebrates. In Culture of Marine Invertebrate Animals; Smith, W.L., Chanley, M.H., Eds.; Plenum Press: New York, NY, USA, 1975.

87. Mabrouk, L.; Hamza, A.; Brahim, M.B.; Bradai, M.N. Temporal and depth distribution of microepiphytes on Posidonia oceanica (L.) Delile leaves in a meadow off Tunisia. Marine Ecol. 2011, 32, 148-161. [CrossRef]

88. Rybak, A.S. The Ulva flexuosa complex (Ulvaceae, Chlorophyta): An updated identification key with special reference to the freshwater and hyperhaline taxa. Phytotaxa 2018, 345, 83-103. [CrossRef]

89. Barreiro Felpeto, A.; Śliwińska-Wilczewska, S.; Złoch, I.; Vasconcelos, V. Light-dependent cytolysis in the allelopathic interaction between picoplanktic and filamentous cyanobacteria. J. Plankton Res. 2018, 40, 165-177. [CrossRef]

90. Guillard, R.R.; Sieracki, M.S. Counting cells in cultures with the light microscope. Algal Cult. Tech. 2005, 16, $239-252$.

91. Strickland, I.D.H.; Parsons, T.R. A practical handbook of seawater analysis. J. Fish. Res. Board Can. 1972, 167, 1-310. 
92. Campbell, D.; Hurry, V.; Clarke, A.K.; Gustafsson, P.; Öquist, G. Chlorophyll fluorescence analysis of cyanobacterial photosynthesis and acclimation. Microbiol. Mol. Biol. Rev. 1998, 62, 667-683. [CrossRef]

93. Perez, J.L.; Chu, T. Effect of Zinc on Microcystis aeruginosa UTEX LB 2385 and Its Toxin Production. Toxins 2020, 12, 92. [CrossRef]

94. Weiss-Hortala, E.; Kruse, A.; Ceccarelli, C.; Barna, R. Influence of phenol on glucose degradation during supercritical water gasification. J. Supercrit. Fluids 2010, 53, 42-47. [CrossRef] 